\title{
A Potent Antimicrobial Peptide Derived from the Protein LsGRP1 of Lilium
}

\author{
Chia-Hua Lin, Min-Wei Chang, and Chao-Ying Chen
}

Department of Plant Pathology and Microbiology, National Taiwan University, Taipei 10617, Taiwan, R.O.C. Accepted for publication 21 October 2013.

\begin{abstract}
Lin, C.-H., Chang, M.-W., and Chen, C.-Y. 2014. A potent antimicrobial peptide derived from the protein LsGRP1 of Lilium. Phytopathology 104:340-346.

LSGRP1 is a defense-related gene differentially expressed in lily leaves in response to pathogen attack. The difficulty in the expression of LsGRP1 in Escherichia coli suggested the presence of antimicrobial activity in LsGRP1. To evaluate the antimicrobial trait of LsGRP1, three LsGRP1-derived peptides were chemically synthesized; namely LsGRP1 $^{\mathrm{N}}$ (N-terminal region without the signal peptide), LsGRP1 ${ }^{\mathrm{G}}$ (glycine-rich region), and LsGRP1 ${ }^{\mathrm{C}}$ (C-terminal cysteine-rich region).

its broad-spectrum and effective antimicrobial activity. LsGRP1C displayed inhibition effects on bacterial and fungal growth, possibly by altering the integrity of the cell membrane, as indicated by scanning electron microscopy and SYTOX Green staining assays. Additionally, LsGRP1 ${ }^{\mathrm{C}}$ induced programmed cell death-like phenomenon in the tested fungal species as indicated by $2^{\prime}, 7^{\prime}$-dichlorodihydrofluorescein diacetate and $4^{\prime}, 6^{\prime}$-diamidino-2-phenylindole assays. Further immunofluorescence staining showed that LsGRP1C ${ }^{\mathrm{C}}$ was located at the fungal cell surface. According to these observations, we concluded that LsGRP1C ${ }^{\mathrm{C}}$ originated from the plant defense-related protein LsGRP1 would play a role as an antimicrobial peptide and have a potential for practical use.
\end{abstract} LsGRP1 ${ }^{\mathrm{C}}$ was proposed to be a potential antimicrobial agent according to
Antimicrobial peptides (AMPs) present in living organisms are natural antibiotics that act as a primary defense barrier to prevent the invasion of pathogenic microorganisms $(10,19)$. Plant AMPs are 3 - to $10-\mathrm{kDa}$ cationic peptides rich in cysteine or glycine residues. These plant AMPs expressing either constitutively or in response to pathogen attack are mostly localized in the extracellular matrix. The structure of plant AMPs is generally stabilized by cysteine-linked intramolecular disulfide bridges which ensure the effective interaction with microbial plasma membrane and lead to disruption of membrane integrity of the microorganism. Other antimicrobial mechanisms of AMPs in addition to membrane permeabilization have been proposed, such as suppression of nucleic acid and protein syntheses, inhibition of enzymatic activity, and induction of programmed cell death $(5,8,20)$. Because AMPs exhibit broad-spectrum antimicrobial activity and diverse mode of actions, they are candidates highly recommended for drug development and agricultural application $(4,18,25)$.

Induced resistance in plants refers to a state with enhanced defense in response to biotic and abiotic stresses $(3,9,24,31)$. The plant hormone salicylic acid is a disease resistance modulator involving in defense signaling and stimulating the expression of numerous defense genes in many plant systems $(1,13)$. LsGRPl (Lilium 'Stargazer' glycine-rich protein 1) is a defense-related gene of lily that increases expression post treatment with either salicylic acid or probenazole and inoculation with fungal pathogen Botrytis elliptica (Berk.) Cooke (6,15-17). LsGRPl encodes a glycine-rich protein of 138 amino acids (aa) with a 23-aa $\mathrm{N}$ terminal signal peptide, which enables translocation of mature protein to the plasma membrane or extracellular matrix. The

Corresponding author: C.-Y. Chen; E-mail address: cychen@ntu.edu.tw

*The $\boldsymbol{e}$-Xtra logo stands for "electronic extra" and indicates that Figures 3, 4, and 5 appear in color online.

http://dx.doi.org/10.1094/PHYTO-09-13-0252-R

(c) 2014 The American Phytopathological Society deduced LsGRP1 sequence shares similarity with various plant GRPs and has a highly conserved domain structure, including a signal peptide (SP), a central glycine-rich domain, and a Cterminal cysteine-rich domain $(6,15-17)$. In our previous observations, using several fusion protein expression systems to express LsGRP1 in Escherichia coli was problematic. The poor yield of fusion protein together with cell aggregation and cell death as indicated by other reports $(2,7)$ suggested that LsGRP1 $\Delta$ SP is toxic to $E$. coli.

In this study, the antimicrobial potential of LsGRP1 $\Delta$ SP was interpreted by antimicrobial assays using three LsGRP1-derived peptides; namely, $\mathrm{LsGRP}^{\mathrm{N}}{ }^{\mathrm{N}} \mathrm{LsGRP} 1^{\mathrm{G}}$, and $\mathrm{LsGRP} 1^{\mathrm{C}}$, corresponding to N-terminal, glycine-rich, and cysteine-rich regions of the deduced LsGRP1, respectively. The mode of action of the LsGRP1-derived peptides exhibiting the most effective antimicrobial activity and the broadest antimicrobial spectrum was further investigated on different aspects such as the alterations of cell morphology and membrane permeability and the induction of programmed cell death.

\section{MATERIALS AND METHODS}

Microorganisms. The bacterial species used in this study included Agrobacterium tumefaciens C58C ${ }^{1}$ (30), Escherichia coli DH5 $\alpha$ (Invitrogen, Carlsbad, CA), Pseudomonas syringae pv. syringae 61 (11), Bacillus subtilis 28-4 and Xanthomonas campestris XCP3 (both from Molecular Plant Pathology Laboratory in Department of Plant Pathology and Microbiology, NTU, Taipei, Taiwan, ROC). These bacterial species were cultured on Luria-Bertani (LB) medium ( $1 \%$ tryptone, $0.5 \%$ yeast extract, $0.5 \% \mathrm{NaCl}$, and $1.5 \%$ agar) and 523 medium (1\% sucrose, $0.8 \%$ casein hydrolysate, $0.4 \%$ yeast extract, $0.2 \% \quad \mathrm{KH}_{2} \mathrm{PO}_{4}, 0.03 \%$ $\mathrm{MgSO}_{4} \cdot 7 \mathrm{H}_{2} \mathrm{O}$ and $1.5 \%$ agar; $\mathrm{pH} 7.0$ ). The incubation temperatures for $E$. coli DH5 $\alpha$ and the other bacterial species were 37 and $28^{\circ} \mathrm{C}$, respectively. For antibacterial assay, bacteria were incubated in $3 \mathrm{ml} \mathrm{LB}$ broth at $180 \mathrm{rpm}$ for 12 to $16 \mathrm{~h}$ and then diluted to a desired concentration using sterile deionized water. 
The fungal species used in this study included Alternaria brassicicola Ac1, Colletotrichum acutatum HL1 (both from Molecular Plant Pathology Laboratory in Department of Plant Pathology and Microbiology, NTU), Botrytis cinerea B-134 and B. elliptica B061 (both from Dr. Ting-Fang Hsieh in Plant Pathology Division, Taiwan Agricultural Institute, Taichung, Taiwan, ROC). B. elliptica B061 was cultured on V8 agar (20\% V8 juice [Campbell Soup Company, Camden, $\mathrm{NJ}$ ], $0.3 \% \mathrm{CaCO}_{3}$, and $1.5 \%$ agar) at $20^{\circ} \mathrm{C}$ for 5 to 8 days whereas the other fungi were cultured on potato dextrose agar (Difco Laboratories, Detroit) at $25^{\circ} \mathrm{C}$ for 7 to 10 days. Spore suspensions of different fungal species were prepared in sterile deionized water and diluted to a desired concentration.

Computational analysis. The antimicrobial activities of LsGRP1 $^{\mathrm{N}}$, LsGRP1 ${ }^{\mathrm{G}}$, and LsGRP1 ${ }^{\mathrm{C}}$ (Fig. 1), which originated from LsGRP1 sequences (National Center for Biotechnology Information accession number AAL61539.1), were analyzed using AMP prediction servers AMPA (27), APD2 (32,33), AntiBP2 (14), CAMP (26), and ClassAMP (12).

Peptide preparation. The chemically synthesized (Genscript USA Inc., Piscataway, NJ) peptides $\mathrm{LsGRP}^{\mathrm{N}}$, LsGRP1 ${ }^{\mathrm{G}}$, and LsGRP1 $^{\mathrm{C}}$ were purified by high-performance liquid chromatography using a solvent system composed of a mixture of acetonitrile, trifluoroacetic acid, and water, all at a purity $>90 \%$. The identity of synthetic peptides was confirmed by electrospray ionization mass spectrometry. Synthetic peptides were dissolved in sterile deionized water at a concentration of $10 \mathrm{mg} / \mathrm{ml}$ and stored at $-20^{\circ} \mathrm{C}$ before use.

Growth inhibition assays. The antibacterial and antifungal activities of these peptides were determined by measuring the inhibition rates of bacterial growth and fungal spore germination. Sterile deionized water instead of the peptide solution was used as a control treatment.

Bacterial suspensions with an optical density at $600 \mathrm{~nm}$ of 0.15 were treated with peptide solutions for $90 \mathrm{~min}$ at the culture temperature of treated bacterial species, then serially diluted and plated on LB medium. After incubation for 20 to $24 \mathrm{~h}$ at their culture temperature, the $\mathrm{CFU}$ in each peptide-treated sample were quantified. Inhibition rate $(\%)=[(\mathrm{CFU}$ in water treatment $-\mathrm{CFU}$ in peptide treatment)/CFU in water treatment] $\times 100 \%$. On the other hand, fungal spore suspensions of $1 \times 10^{5}$ or $5 \times 10^{4}$ spores $/ \mathrm{ml}$ were treated with peptide solutions at the culture temperature of treated fungal species for 16 to $20 \mathrm{~h}$ and then the spore germinations were examined under the microscope. A germ tube greater than two times the spore length was considered germinated. Inhibition rate $(\%)=[($ number of spores germinating in water - number of spores germinating in peptide solution)/ number of spores germinating in water] $\times 100 \%$. All assays were performed in triplicate. Based on the data, the concentrations of peptide for $50 \%$ growth inhibition $\left(\mathrm{IC}_{50}\right)$ of each microbe were determined.

Scanning electron microscopy. The morphological change of bacterial cells was examined by scanning electron microscopy (SEM). Cover slides precoated with $0.1 \%$ poly-L-lysine were deposited with $20 \mu \mathrm{l}$ of a bacterial suspension of $10^{8}$ cells $/ \mathrm{ml}$ and kept moist at $28^{\circ} \mathrm{C}$ for $12 \mathrm{~h}$. The bacterial colonies attached to the cover slides were treated with $20 \mu \mathrm{l}$ of peptide solution for $2 \mathrm{~h}$. Then, the cells were fixed using $1 \%$ glutaraldehyde and washed

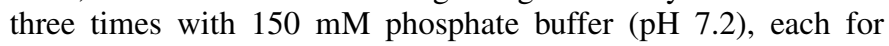
15 min. Next, the cells on the slides were coated with $1 \% \mathrm{OsO}_{4}$ for $1 \mathrm{~h}$, immersed in $2 \%$ uranyl acetate for $30 \mathrm{~min}$, and washed three times with $150 \mathrm{mM}$ phosphate buffer $(\mathrm{pH} \mathrm{7.2)}$, each for $15 \mathrm{~min}$. The samples were dehydrated serially using 30, 50, 70, $85,90,95$, and $100 \%$ (twice) ethanol, each for $30 \mathrm{~min}$, and soaked twice in acetone, each for $30 \mathrm{~min}$, then dried in $\mathrm{CO}_{2}$ by using a critical point dryer HCP-2 (Hitachi, Tokyo) and coated with gold particles in an ion sputter E101 (Hitachi). Afterward, the prepared samples were examined under a scanning electron microscope (Inspect S; FEI Company, Hillsboro, OR).

SYTOX Green staining. The alteration of cell membrane permeability of bacterial and fungal cells was examined by SYTOX Green staining. Bacterial suspensions of $1 \times 10^{8}$ cells $/ \mathrm{ml}$ were treated with peptide solution in the presence of $1 \mu \mathrm{M}$ SYTOX Green (Invitrogen) and incubated at $28^{\circ} \mathrm{C}$ and $180 \mathrm{rpm}$ for $2 \mathrm{~h}$ before observation under a Leica DMR fluorescence microscope equipped with a Chroma Endow green fluorescent protein filter set (a 450 to $490 \mathrm{~nm}$ band-pass excitation filter, a $495 \mathrm{~nm}$ dichroic mirror, and a 500 to $550 \mathrm{~nm}$ band-pass emission filter). Fungal spores and hyphae were treated with peptide solution at $50 \mu \mathrm{g} / \mathrm{ml}$ for 2 and $16 \mathrm{~h}$, respectively. Then, the fungal cells were stained with SYTOX Green at $1 \mu \mathrm{g} / \mathrm{ml}$ in the dark for 10 min before observation under a Leica DMIL fluorescent microscope equipped with a Chroma 41012 filter set (a 460 to $500 \mathrm{~nm}$ band-pass excitation filter, a $505 \mathrm{~nm}$ dichroic mirror, and a $510 \mathrm{~nm}$ long-pass emission filter).

$\mathbf{2}^{\prime}, \mathbf{7}^{\prime}$-Dichlorodihydrofluorescein diacetate staining. The accumulation of reactive oxygen species (ROS) in the fungal cells in response to peptide treatment was examined by $2^{\prime}, 7^{\prime}$-dichlorodihydrofluorescein diacetate $\left(\mathrm{H}_{2} \mathrm{DCFDA}\right)$ staining. Fungal spores and hyphae were treated with peptide solution at $50 \mu \mathrm{g} / \mathrm{ml}$ for 2 and $16 \mathrm{~h}$, respectively. Then, the fungal cells were stained with $10 \mu \mathrm{M} \mathrm{H}_{2}$ DCFDA in the dark for $60 \mathrm{~min}$ before observation under

LsGRP1 (accession number: AAL61539.1)

\begin{tabular}{|c|c|c|c|}
\hline $\begin{array}{c}\text { Signal peptide } \\
1^{\text {st }}-23^{\text {th }} \text { a.a. }\end{array}$ & $\begin{array}{c}\text { LsGRP1 }^{\mathrm{N}} \\
24^{\text {th }}-49^{\text {th }} \text { a.a. }\end{array}$ & $\begin{array}{c}\text { LsGRP1 }^{\mathrm{G}} \\
5^{\text {th }}-100^{\text {th }} \text { a.a. }\end{array}$ & $\begin{array}{c}\text { LsGRP1 }^{\text {C }} \\
101^{\text {th }}-138^{\text {th }} \text { a.a. }\end{array}$ \\
\hline \multirow[b]{2}{*}{ Prediction server } & \multicolumn{3}{|c|}{ LsGRP1-derived peptide } \\
\hline & LsGRP1 $^{\mathrm{N}}$ & LsGRP1G $^{\mathrm{G}}$ & LsGRP1C $^{\mathrm{C}}$ \\
\hline AMPA & + & + & + \\
\hline APD2 & - & $+1-$ & + \\
\hline AntiBP2 & - & - & + \\
\hline CAMP & - & + & $+1-$ \\
\hline ClassAMP & + & + & + \\
\hline
\end{tabular}

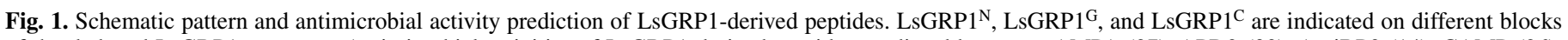

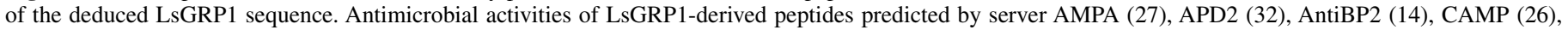

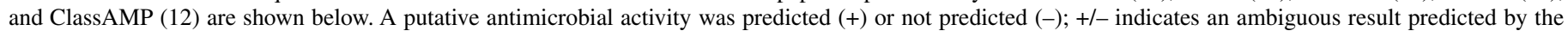
server. 
a Leica DMIL florescent microscope equipped with a Chroma 41012 filter set.

4',6'-Diamidino-2-phenylindole staining. The programmed cell death phenomenon of the fungal cells in response to peptide treatment was examined by $4^{\prime}, 6^{\prime}$-diamidino-2-phenylindole (DAPI) staining. Fungal spores and hyphae were treated with peptide solution at $50 \mu \mathrm{g} / \mathrm{ml}$ for 2 and $16 \mathrm{~h}$, respectively. Then, the fungal cells were stained with DAPI at $1 \mu \mathrm{g} / \mathrm{ml}$ in the dark for 10 min before observation under a Leica DMIL florescent microscope equipped with a Leica A filter set (a 340 to $380 \mathrm{~nm}$ band-pass excitation filter, a $400 \mathrm{~nm}$ dichroic mirror, and a $425 \mathrm{~nm}$ long-pass emission filter).

Immunofluorescence microscopy. To examine the location of peptide molecules on the fungal cells treated, immunofluorescence microscopy was performed. At first, the fungal hyphae treated with peptide solution at $50 \mu \mathrm{g} / \mathrm{ml}$ for $16 \mathrm{~h}$ were fixed with $4 \%$ formaldehyde in phosphate-buffered saline (PBS) $(137 \mathrm{mM}$ $\mathrm{NaCl}, 2.7 \mathrm{mM} \mathrm{KCl}, 10 \mathrm{mM} \mathrm{Na} \mathrm{HPO}_{4}$, and $2 \mathrm{mM} \mathrm{KH}_{2} \mathrm{PO}_{4} ; \mathrm{pH}$ 7.4) for $1 \mathrm{~h}$, treated with $25 \mathrm{mM}$ dithiothreitol in PBS for $20 \mathrm{~min}$, then digested with chitinase at $20 \mathrm{mg} / \mathrm{ml}$ in PBS containing $\beta$ mercaptoethanol at $5 \mu \mathrm{l} / \mathrm{ml}$ for $30 \mathrm{~min}$. Afterward, the hyphae were immunostained using $\mathrm{LsGRP} 1^{\mathrm{C}}$ antibody and fluorescein isothiocyanate-labeled anti-rabbit immunoglobulin $\mathrm{G}$ antibody (KPL, Gaithersburg, MD). The hyphae were observed under a Leica DMIL florescent microscope equipped with a CHROMA 41012 filter set. LsGRP1 $^{\mathrm{C}}$ antibody was prepared from the antiserum of the rabbit immunized with chemically synthesized partial C-terminal sequences of the deduced LsGRP1 (accession number AAL61539.1) by purification with the $\mathrm{LSGRP} 1^{\mathrm{C}}$ affinity column.

\section{RESULTS}

Prediction of antimicrobial activity. $\operatorname{LsGRP} 1^{\mathrm{N}}, \mathrm{LsGRP} 1^{\mathrm{G}}$, and LsGRP1 $^{\mathrm{C}}$ were assessed for antimicrobial activity using different AMP prediction servers. Antimicrobial activity of LsGRP1 ${ }^{\mathrm{C}}$ was suggested by all five servers used whereas antimicrobial potentials of $\mathrm{LsGRP}^{\mathrm{N}}$ and $\mathrm{LsGRP}^{\mathrm{G}}$ were only supported by two and four servers, respectively (Fig. 1).

Antibacterial activity of LsGRP1-derived peptides. In an antibacterial assay, the growths of five bacterial species were significantly inhibited in the presence of LsGRP1-derived peptides at a concentration of $2.5 \mathrm{mg} / \mathrm{ml}$ (Fig. 2A). Both LsGRP1 ${ }^{\mathrm{N}}$ and $\mathrm{LsGRP} 1^{\mathrm{C}}$ caused $>99.5 \%$ growth inhibition on all bacterial species tested. Although LsGRP $1^{\mathrm{G}}$ caused $>99.5 \%$ inhibition on the growth of $A$. tumefaciens $\mathrm{C} 58 \mathrm{C}^{1}$, it showed a lower inhibitory effect on B. subtilis 28-4 (87.6\%), E. coli DH5 $\alpha$ (81.8\%), $P$. syringae pv. syringae $61(84.8 \%)$, and $X$. campestris XCP3 (69.6\%). Thus, LsGRP1 ${ }^{\mathrm{N}}$ and LsGRP1 ${ }^{\mathrm{C}}$ exhibited higher growth inhibition abilities on the bacteria compared with $\mathrm{LsGRP}^{\mathrm{G}}$.

Antifungal activity of LsGRP1-derived peptides. The antifungal activities of the LsGRP1-derived peptides were investigated by measuring the inhibition rate of spore germination, and LsGRP1 ${ }^{\mathrm{C}}$ exhibited the highest inhibition activity and broadest spectrum compared with $\mathrm{LsGRP} 1^{\mathrm{N}}$ and $\mathrm{LsGRP} 1^{\mathrm{G}}$ (Fig. 2B). At a concentration as high as $2.5 \mathrm{mg} / \mathrm{ml}, \mathrm{LsGRP}^{\mathrm{C}}$ inhibited spore

\section{A}

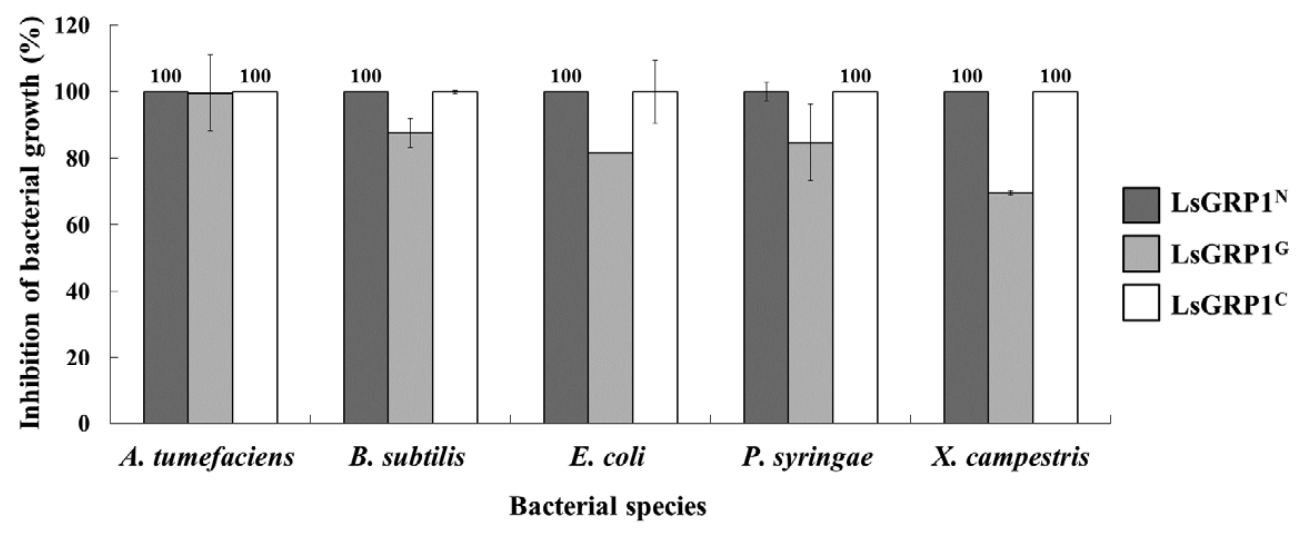

B

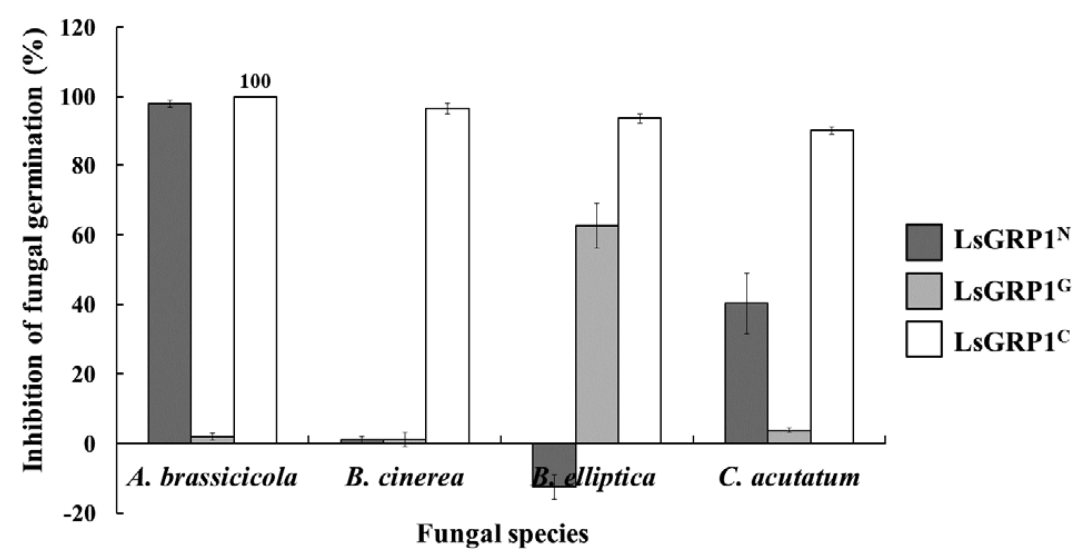

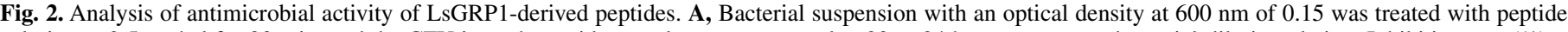

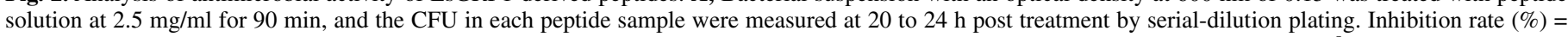

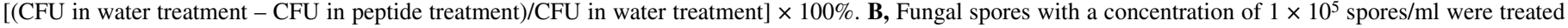

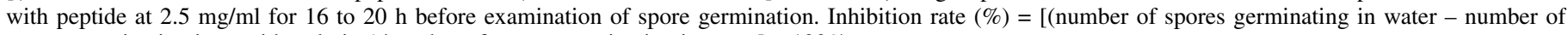
spores germinating in peptide solution)/number of spores germinating in water] $\times 100 \%$. 
germination by $>90 \%$ in all assayed fungal species: $A$. brassicicola Ac1, B. cinerea B-134, B. elliptica B061, and C. acutatum HL1. On the other hand, LsGRP1 $1^{\mathrm{N}}$ inhibited spore germinations of A. brassicicola Ac1 and C. acutatum HL1 by 98.0 and $40.3 \%$, respectively. The spore germination of $B$. cinerea B-134 was not affected by LsGRP1 ${ }^{\mathrm{N}}$. Worthy of notice, LsGRP1 ${ }^{\mathrm{N}}$ slightly enhanced spore germination of B. elliptica B061 (-12.4\% inhibi-

TABLE 1 . The $50 \%$ inhibitory concentrations $\left(\mathrm{IC}_{50}\right)$ of $\mathrm{LsGRP}^{\mathrm{C}}$ for bacterial and fungal species

\begin{tabular}{lc}
\hline Microorganism & $\mathrm{IC}_{50}(\mu \mathrm{g} / \mathrm{ml})$ \\
\hline Bacterial species $^{\mathrm{a}}$ & \\
${\text { Agrobacterium tumefaciens } \text { C58C }^{1}}^{\text {Bacillus subtilis } 28-4}$ & 71.79 \\
Escherichia coli $\mathrm{DH}$ 5 $\alpha$ & 23.32 \\
Pseudomonas syringae pv. syringae 61 & 9.67 \\
Xanthomonas campestris XCP3 & 20.63 \\
Fungal species & 32.19 \\
Alternaria brassicicola Ac1 & \\
Botrytis elliptica B061 & 54.80 \\
Botrytis cinerea B-134 & 86.13 \\
Colletotrichum acutatum HL1 & 58.26 \\
\hline
\end{tabular}

${ }^{a}$ Inhibition of bacterial growth was measured (initial optical density at $600 \mathrm{~nm}=0.15$ )

${ }^{b}$ Inhibition of fungal spore germination $\left(5 \times 10^{4}\right.$ spores $\left./ \mathrm{ml}\right)$ was measured. tion rate). In contrast to $\mathrm{LsGRP} 1^{\mathrm{N}}$ and $\mathrm{LsGRP} 1^{\mathrm{C}}, \mathrm{LsGRP} 1^{\mathrm{G}}$ did not inhibit spore germination, with the exception of $B$. elliptica B061 (62.7\% inhibition rate). Hence, LsGRP1 ${ }^{\mathrm{C}}$ is a more potent antifungal peptide compared with $\mathrm{LsGRP}^{\mathrm{N}}$ and LsGRP1 ${ }^{\mathrm{G}}$.

LsGRP1 ${ }^{\mathrm{C}}$ exhibited effective inhibition on bacterial and fungal species. To further demonstrate the antimicrobial activity of $\mathrm{LsGRP}^{\mathrm{C}}$, the $\mathrm{IC}_{50}$ values of $\mathrm{LsGRP}^{\mathrm{C}}$ on different bacterial and fungal species were determined. The $\mathrm{IC}_{50}$ values of $\mathrm{LsGRP} 1^{\mathrm{C}}$ on the assayed microbes were all $<90 \mu \mathrm{g} / \mathrm{ml}$ (Table 1). With the exception of $A$. tumefaciens $\mathrm{C}_{58 \mathrm{C}}{ }^{1}\left(\mathrm{IC}_{50}=71.79 \mu \mathrm{g} / \mathrm{ml}\right)$, the $\mathrm{IC}_{50}$ values of $\mathrm{LsGRP} 1^{\mathrm{C}}$ on all assayed bacterial species were $<35 \mu \mathrm{g} / \mathrm{ml}$, with E. coli DH5 $\alpha$ being most sensitive to LsGRP1 ${ }^{\mathrm{C}}$ $\left(\mathrm{IC}_{50}=9.67 \mu \mathrm{g} / \mathrm{ml}\right)$. On the other hand, the $\mathrm{IC}_{50}$ values of the assayed fungal species were $<60 \mu \mathrm{g} / \mathrm{ml}$, except that the causal pathogen of lily leaf blight, B. elliptica, exhibited higher tolerance to $\mathrm{LsGRP}^{\mathrm{C}}\left(\mathrm{IC}_{50}=86.13 \mu \mathrm{g} / \mathrm{ml}\right)$.

LsGRP1 $^{\mathrm{C}}$ altered bacterial morphology and membrane permeability. The effects of $\mathrm{LsGRP} 1^{\mathrm{C}}$ on the morphology of two plant-pathogenic bacteria, $P$. syringae pv. syringae 61 and $X$. campestris XCP3, were examined by SEM. After co-incubation with LsGRP1 ${ }^{\mathrm{C}}$ at $25 \mu \mathrm{g} / \mathrm{ml}$, the cells of $P$. syringae pv. syringae 61 and $X$. campestris XCP3 exhibited a shortened, wrinkled, and melted morphology (Fig. 3A). When the concentration of LsGRP1 $1^{\mathrm{C}}$ treatment increased to $250 \mu \mathrm{g} / \mathrm{ml}$, the surface of treated

A

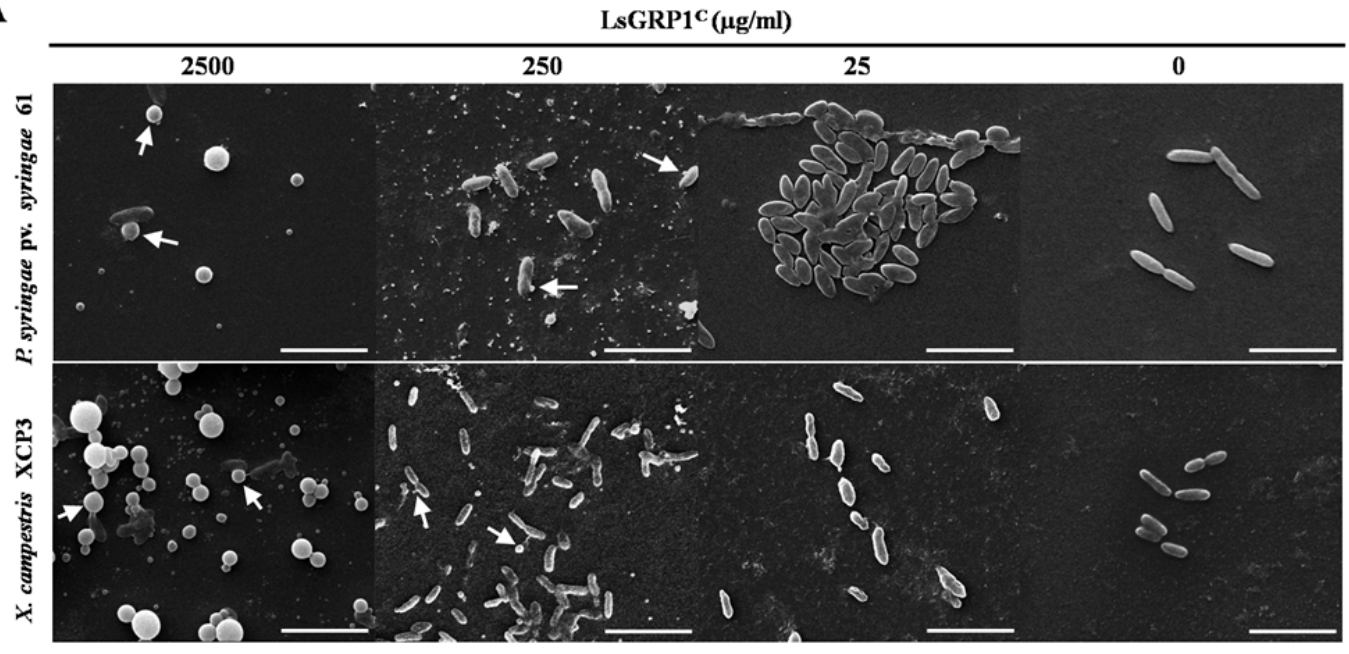

B

$\operatorname{LsGRP1}^{c}(\mu \mathrm{g} / \mathrm{ml})$

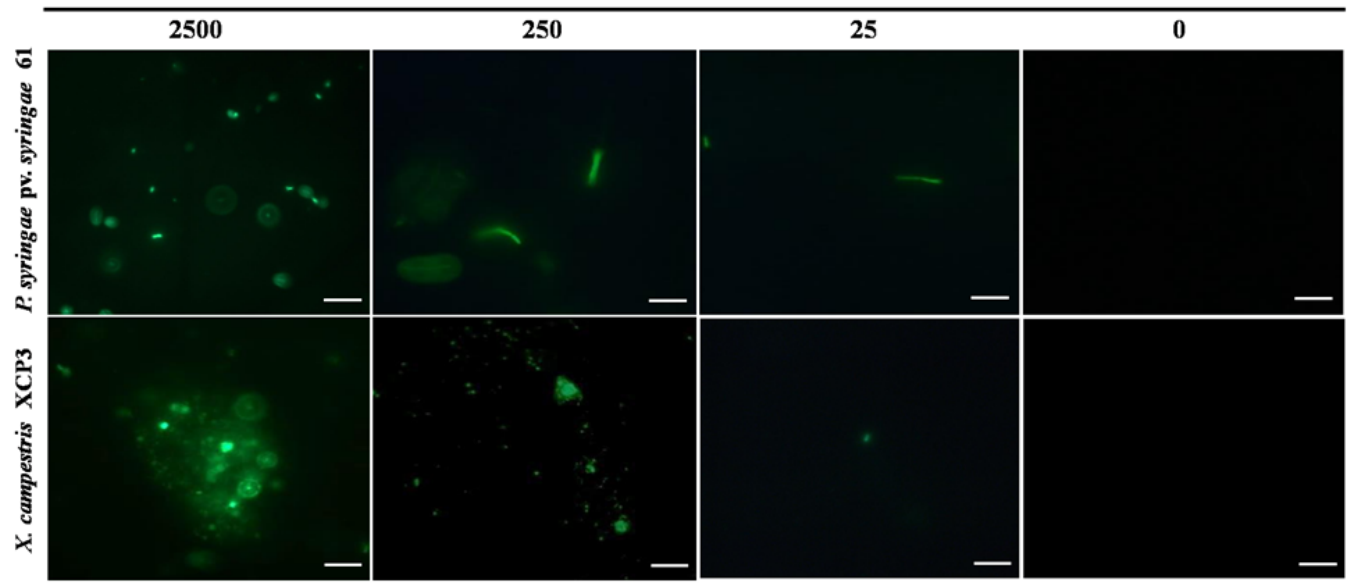

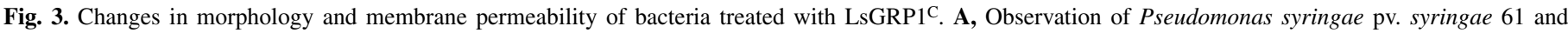

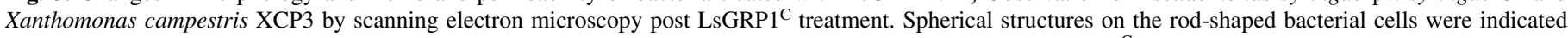
by arrows. Bar $=4 \mu \mathrm{m}$. B, SYTOX-Green-stained $P$. syringae pv. syringae 61 and $X$. campestris XCP3 post LsGRP1C treatment. Bar $=10 \mu \mathrm{m}$. 
cells became coarser, with some knurls and bubble-like appearance. At a concentration of $\mathrm{LsGRP}^{\mathrm{C}}$ as high as $2,500 \mu \mathrm{g} / \mathrm{ml}$, a significant number of spherical particles of different sizes were observed and some of them had a budding appearance. Besides, the spherical particles were associated with collapsed cells in a rod shape. In addition, to verify the effect of LsGRP1 ${ }^{\mathrm{C}}$ on bacterial membranes, a nucleic acid dye, SYTOX Green, impermeable to normal cells but penetrating to damaged cell membranes and causing florescent nuclei, was used. The SYTOX Green-stained bacterial cells were observed in $P$. syringae pv. syringae 61 and $X$. campestris XCP3 after LsGRP1 ${ }^{\mathrm{C}}$ treatment (Fig. 3B) whereas the control without $\mathrm{LsGRP} 1^{\mathrm{C}}$ treatment did not show the fluorescent cells in the assayed bacterial species, indicating that $\mathrm{LsGRP}^{\mathrm{C}}$ destroyed the integrity of bacterial membranes.

LSGRP1 $^{\mathrm{C}}$ destroyed membrane integrity and induced programmed cell death-like phenomenon in fungi. The effects of LsGRP1 $1^{\mathrm{C}}$ on spores and hyphae of $A$. brassicicola Ac1, B. cinerea B-134, B. elliptica B061, and $C$. acutatum HL1 were demonstrated (Fig. 4). As observed under a light microscope, the spores and hyphae of LsGRP1 ${ }^{\mathrm{C}}$-treated fungal species, especially B. elliptica, the causal pathogen of lily leaf blight, exhibited bleb and shrinkage on the cell surface as well as necrotic and granular in the cytoplasm. In contrast, the surfaces of the fungal spores and hyphae in the control were smooth and intact, and the cytoplasms of different assayed fungi all had a homogeneous feature without granulation and necrosis.
Damage to the plasma membrane of spores and hyphae caused by LsGRP $1{ }^{\mathrm{C}}$ appeared in all fungal species examined. In addition, DAPI staining showed that LsGRP1 ${ }^{\mathrm{C}}$ treatment led to nuclear chromatin condensation in these fungal species examined (Fig. 4). The accumulations of ROS in the hyphae of the fungi pretreated with LsGRP $^{\mathrm{C}}{ }^{\text {}}$ were visualized by $\mathrm{H}_{2}$ DCFDA staining (Fig. 4B). These effects of LsGRP $^{\mathrm{C}}$ treatment as detected by SYTOX Green, DAPI, and $\mathrm{H}_{2}$ DCFDA staining were absent in the control. Interestingly, the ROS accumulation triggered by $\mathrm{LSGRP} 1^{\mathrm{C}}$ was absent in the ungerminated spores of the fungal species examined, except that of B. elliptica (Fig. 4A).

The location of LsGRP1 $^{\mathrm{C}}$ on the treated fungal cells. LsGRP1 ${ }^{\mathrm{C}}$-treated hyphae fluoresced in the fungal species tested whereas no signal was observed in the water control (Fig. 5). Most fluorescent signals were located at the outer layer of the hyphae and only a few were found inside the hyphal cells.

\section{DISCUSSION}

Cysteine and glycine are the most abundant amino acids in plant AMPs $(10,32)$. The LsGRP1, a defense-related protein of Lilium, also contains cysteine- and glycine-rich regions. The cysteine-rich C-terminal region of LsGRP1, among the three regions evaluated, was selected by the prediction servers as the best candidate to possess antimicrobial activities.

Although the three LsGRP1-derived peptides effectively inhibited all of the bacterial species investigated (70 to $100 \%$

\section{$\mathbf{A}$}
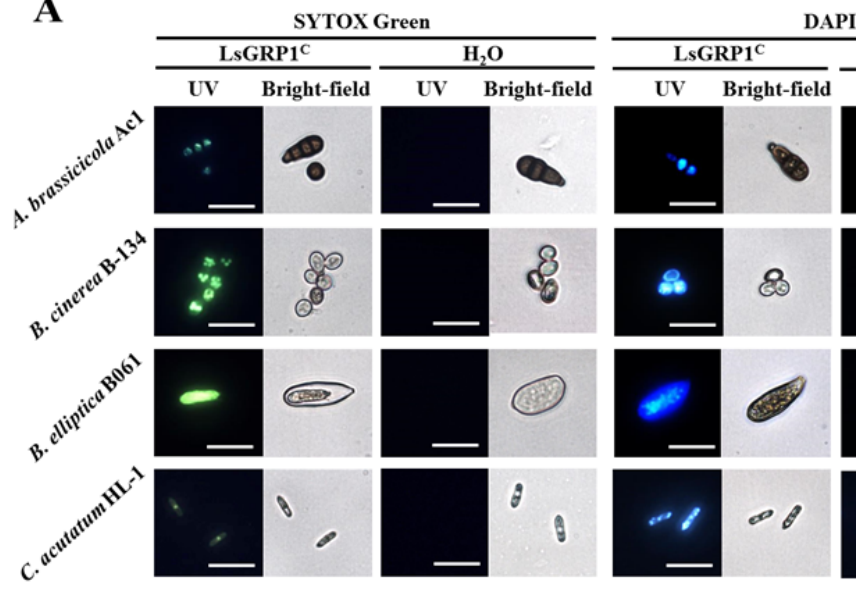

DAPI

$\frac{\mathrm{H}_{2} \mathrm{O}}{\text { UV Bright-field }}$

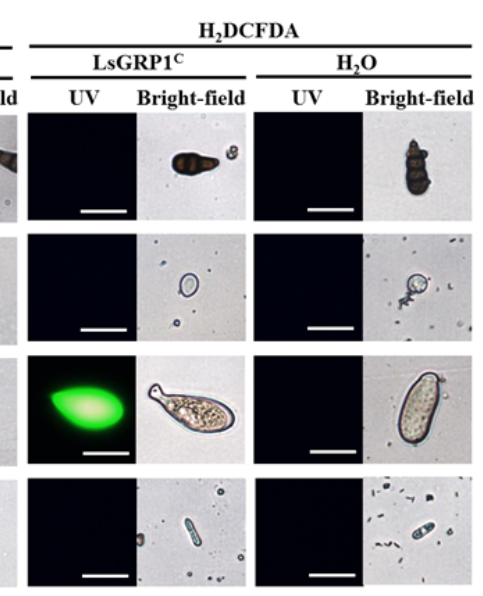

B

B
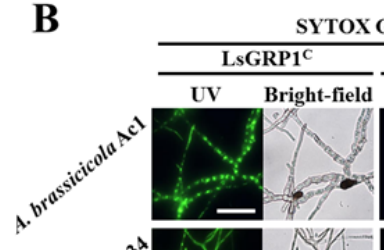

SYTOX Green
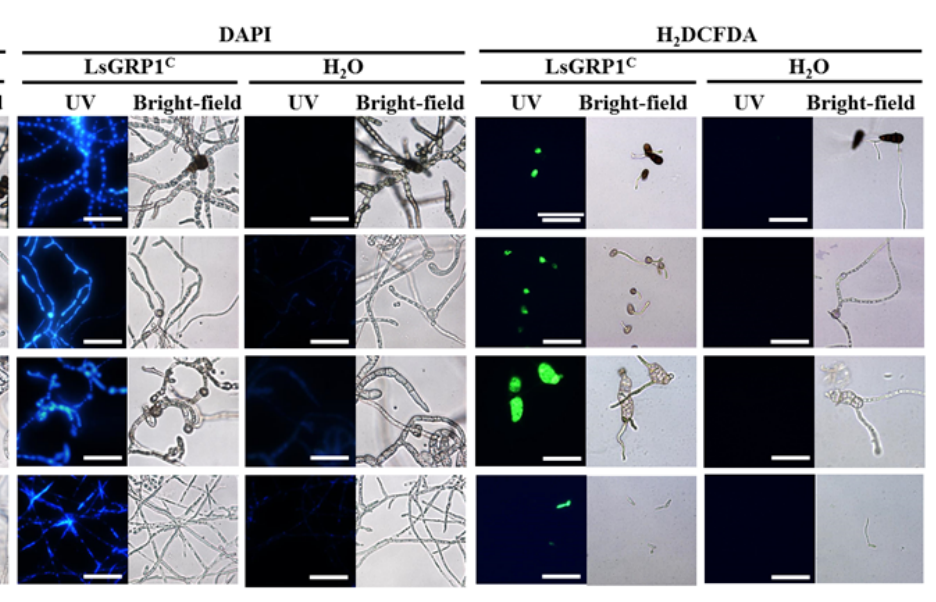

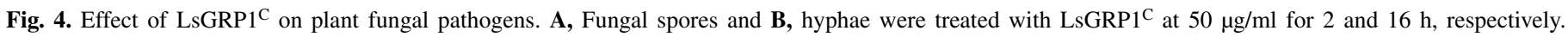

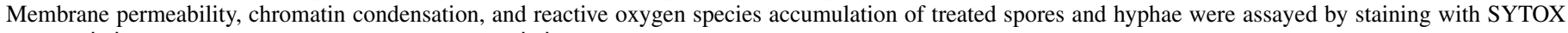

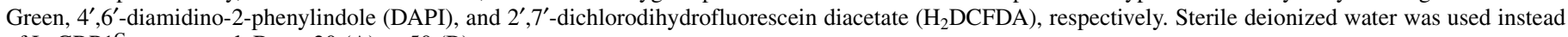
of $\mathrm{LsGRP} 1^{\mathrm{C}}$ as a control. Bar $=20$ (A) or 50 (B) $\mu \mathrm{m}$. 
inhibition), only LsGRP1 ${ }^{\mathrm{C}}$ inhibited all the fungal strains investigated to a high degree as predicted by AMP prediction servers. The antimicrobial strength and spectrum of LsGRP $^{\mathrm{C}}{ }^{\mathrm{C}}$ were further demonstrated by the low $\mathrm{IC}_{50}$ values on the bacterial and fungal species examined. The $\mathrm{IC}_{50}$ values of these $\mathrm{LsGRP} 1^{\mathrm{C}}$ treated microbes were all $<90 \mu \mathrm{g} / \mathrm{ml}$, well within the effective range of known AMPs (19). The combined traits of effective inhibitory activity and broad antimicrobial spectrum of LsGRP1 ${ }^{\mathrm{C}}$ suggested that this peptide could act on certain common targets or has multiple effects on microbial physiology. The LsGRP1 ${ }^{\mathrm{C}}$ treated cells of $P$. syringae pv. syringae 61 and $X$. campestris XCP3 exhibited a shortened and shrinkage feature at lower concentration and turned into a spherical shape at higher concentrations, indicating that the cell morphological changes of the two bacterial species examined were dose dependent. The morphological change of bacterial cells also implied that cell membrane damage might be involved and supported by SYTOX Green staining results. SYTOX Green is impermeable to normal cells but penetrates damaged cell membrane and stains the nucleic acid. The fact that SYTOX-Green-stained nucleic acids were observed in $P$. syringae pv. syringae 61 and $X$. campestris XCP3 cells treated with $\mathrm{LsGRP} 1^{\mathrm{C}}$ but not with the control indicated that LsGRP $1{ }^{\mathrm{C}}$ changed the permeability of bacterial membranes by compromising the membrane integrity. Consistent with the dosedependent morphological change, the proportion of SYTOXGreen-stained bacteria was positively correlated to the concentration of $\mathrm{LsGRP}^{\mathrm{C}}$ used in the treatment. The changes in morphology and membrane permeability of bacteria triggered by LsGRP1 ${ }^{\mathrm{C}}$ are similar to the alterations that occurred in irreversible terminal differentiation of nitrogen-fixing bacteria into bacteroids, which is governed by AMP-like nodule-specific cysteinerich peptides secreted by the inverted repeat-lacking clade of legumes during symbiosis (29). In addition, because the synthesis of peptidoglycan sacculus, the major contributor to maintain bacterial morphology, is associated with the bacterial membrane (28), it might be involved in the mechanism of bacterial morphology change induced by $\mathrm{LsGRP} 1^{\mathrm{C}}$.

Damage to the plasma membrane of spores and hyphae by the treatment with LsGRP1 $^{\mathrm{C}}$ demonstrated that $\mathrm{LsGRP} 1^{\mathrm{C}}$ also affected the membrane integrity of all fungal species tested. In the SYTOX Green staining assay, $\mathrm{LsGRP}^{\mathrm{C}}$ was shown to disrupt the membrane integrity of both bacterial and fungal cells, representing a common property of cationic cysteine-rich AMPs $(5,20)$. Moreover, the predominant association of $\mathrm{LsGRP} 1^{\mathrm{C}}$ with the cell surface of fungal hyphae indicated that the location of the acting target of LsGRP $1{ }^{C}$ was primarily on the cell wall or plasma membrane. In addition to membrane permeability change, LsGRP1 ${ }^{\mathrm{C}}$ also caused nuclear chromatin condensation and ROS accumulation in the hyphae of all fungal species tested, indicating occurrence of the programmed cell death phenomenon of fungi (21). Because $\mathrm{H}_{2}$ DCFDA used for ROS detection is a membranepermeant ionic molecule naturally trapped inside the cell, the efficiency of ROS staining would not be influenced by LsGRP1 ${ }^{\mathrm{C}}$ triggered fungal membrane permeability. However, the ROS

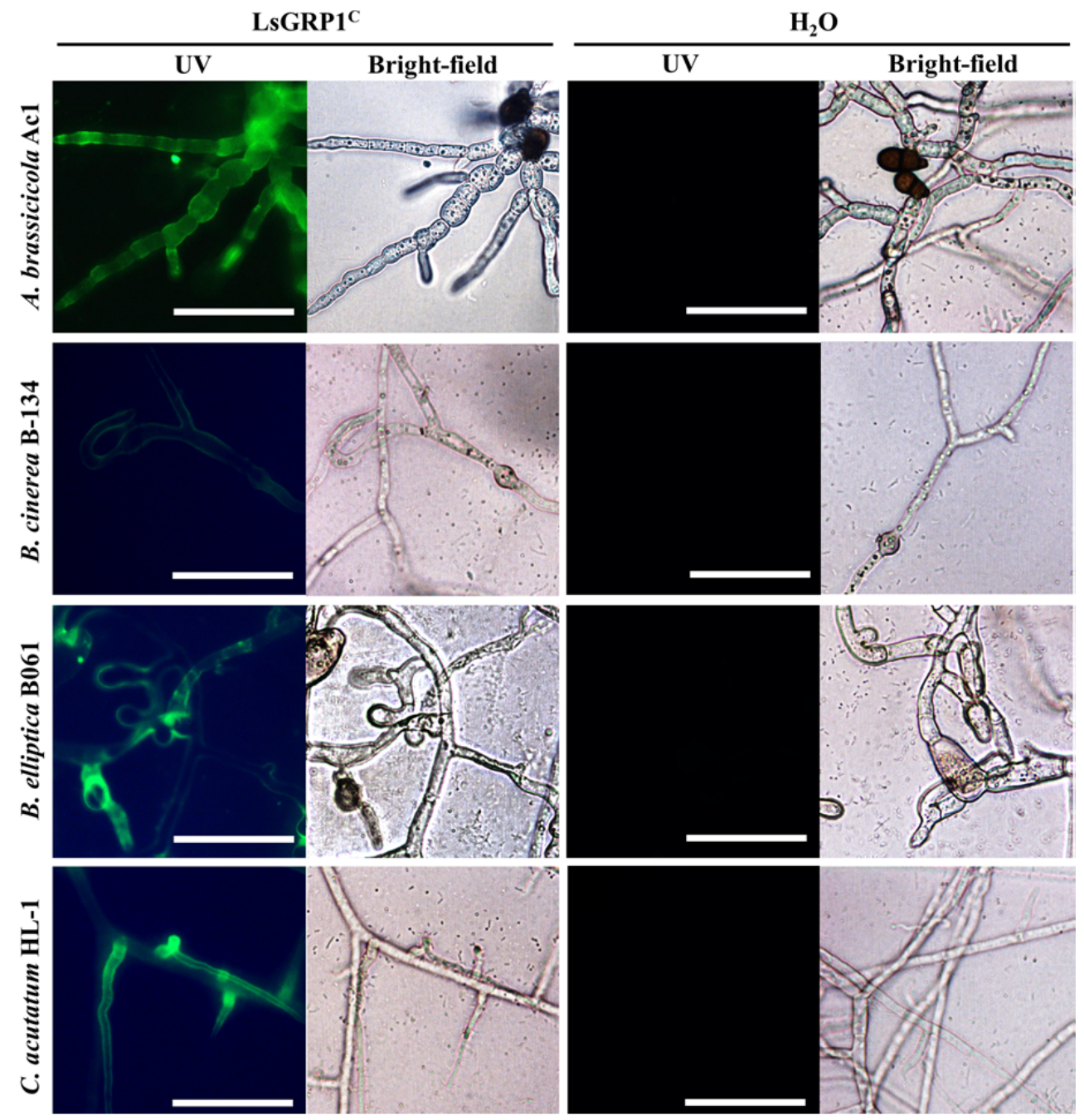

Fig. 5. Immunofluorescence staining of LsGRP1 ${ }^{\mathrm{C}}$ on the hyphae of plant fungal pathogens. Fungal hyphae were treated with $\mathrm{LsGRP} 1^{\mathrm{C}}$ at $50 \mu \mathrm{g} / \mathrm{ml}$ for $16 \mathrm{~h} \mathrm{before}$ immunofluorescence staining. Sterile deionized water was used instead of LsGRP1C as a control. Bar $=25 \mu \mathrm{m}$. 
responses were different in the fungal spores, suggesting that a different role was played by $L s G R P 1^{C}$ in the interaction between fungal spores and plants. Because only the spores of B. elliptica, a lily pathogen, exhibited an earlier ROS accumulation in response to the presence of $\mathrm{LsGRP} 1^{\mathrm{C}}$ compared with other tested fungal species, the higher sensitivity to $\mathrm{LsGRP}^{\mathrm{C}}$ of $\mathrm{B}$. elliptica was probably due to host-specific recognition. Therefore, LsGRP1 ${ }^{\mathrm{C}}$ might not only directly alter membrane integrity in both bacterial and fungal microorganisms but also induce programmed cell death-like phenomenon, at least in some fungi. This feature was also observed in other antifungal peptides and proteins originating from different kinds of microorganisms, plants, and animals (8). Thus, the antimicrobial activity of LsGRP1 ${ }^{\mathrm{C}}$ might be a result of multiple effects on microorganisms.

$L s G R P 1$ is a defense-related gene with an increased expression in lily leaves exhibiting salicylic acid-induced systemic resistance against $B$. elliptica $(6,16)$, and it could enhance disease resistance in vivo when expressed in Arabidopsis thaliana and Nicotiana benthamiana (unpublished data). A number of plant AMPs and antimicrobial compounds have been suggested as inducers of programmed cell death in fungi $(8,20,22,23)$. In this study, the in vitro inhibitory mechanism of $\mathrm{LsGRP} 1^{\mathrm{C}}$ on $B$. elliptica, a lily fungal pathogen, suggested that LsGRP1 might confer plant disease resistance via inducing fungal membrane permeabilization and programmed cell death. In contrast, the slight enhancement of spore germination in B. elliptica caused by LsGRP1 ${ }^{\mathrm{N}}$ treatment might be due to $B$. elliptica recognizing the corresponding region of LsGRP1 as a host signal resulting from the long-term coevolution of B. elliptica and lily. However, to understand the underlying mechanisms of the effects of different regions of LsGRP1 on $B$. elliptica will require further investigation.

LsGRP1 $^{\mathrm{N}}$, LsGRP1 ${ }^{\mathrm{G}}$, and LsGRP1 ${ }^{\mathrm{C}}$ all exhibited high growth inhibition activities on both gram-positive and gram-negative bacteria, suggesting that all three regions might contribute to the unsuccessful expression of LsGRP1 protein in the E. coli system in our previous observation. In this study, the low $\mathrm{IC}_{50}$ value of LsGRP1 $1^{\mathrm{C}}$ on $E$. coli $\mathrm{DH} 5 \alpha(9.67 \mu \mathrm{g} / \mathrm{ml})$ also indicated that $E$. coli would be particularly sensitive to the expressed LsGRP1-bearing C-terminal cysteine region. Because the antimicrobial potency of LsGRP1 $1^{\mathrm{C}}$ on different bacterial and fungal species was demonstrated herein, defense-related proteins that failed to express in a microbial system as LsGRP1 could be strong candidates as novel AMPs.

\section{ACKNOWLEDGMENTS}

The Council of Agriculture and National Science Council, Taiwan, Republic of China financially supported this study. We thank E.-M. Lai and H.-C. Huang for providing A. tumefaciens $\mathrm{C}_{58} \mathrm{C}^{1}$ and $P$. syringe pv. syringae 61, and T.-F. Hsieh for providing B. elliptica B061 and B. cinerea $\mathrm{B}-134$.

\section{LITERATURE CITED}

1. Alvarez, M. E. 2000. Salicylic acid in the machinery of hypersensitive cell death and disease resistance. Plant Mol. Biol. 44:429-442.

2. Baneyx, F., and Mujacic, M. 2004. Recombinant protein folding and misfolding in Escherichia coli. Nat. Biotechnol. 22:1399-1408.

3. Bostock, R. M. 1999. Signal conflicts and synergies in induced resistance to multiple attackers. Physiol. Mol. Plant Pathol. 55:99-109.

4. Brandenburg, L. O., Merres, J., Albrecht, L. J., Varoga, D., and Pufe, T. 2012. Antimicrobial peptides: multifunctional drugs for different applications. Polymers 4:539-560.

5. Brogden, K. A. 2005. Antimicrobial peptides: pore formers or metabolic inhibitors in bacteria? Nat. Rev. Microbiol. 3:238-250.

6. Chen, C. Y., Lu, Y. Y., and Chung, J. C. 2003. Induced host resistance against Botrytis leaf blight. Page 259-267 in: Advances in Plant Disease Management. Research Signpost, Trivandrum, Kerala, India.

7. Chou, C. P. 2007. Engineering cell physiology to enhance recombinant protein production in Escherichia coli. Appl. Microbiol. Biotechnol.
76:521-532.

8. De Brucker, K., Cammue, B. P. A., and Thevissen, K. 2011. Apoptosisinducing antifungal peptides and proteins. Biochem. Soc. Trans. 39:15271532.

9. Durrant, W. E., and Dong, X. 2004. Systemic acquired resistance. Annu. Rev. Phytopathol. 42:185-209.

10. Hammami, R., Ben Hamida, J., Vergoten, G., and Fliss, I. 2009. PhytAMP: A database dedicated to antimicrobial plant peptides. Nucleic Acids Res. 37:D963-D968.

11. Huang, H. C., Schuurink, R., Denny, T. P., Atkinson, M. M., Baker, C. J., Yucel, I., Hutcheson, S. W., and Collmer, A. 1988. Molecular cloning of a Pseudomonas syringae pv. syringae gene cluster that enables Pseudomonas fluorescens to elicit the hypersensitive response in tobacco plants. J. Bacteriol. 170:4748-4756.

12. Joseph, S., Karnik, S., Nilawe, P., Jayaraman, V. K., and Idicula-Thomas, S. 2012. ClassAMP: a prediction tool for classification of antimicrobial peptides. IEEE/ACM Trans. Comput. Biol. Bioinform. 9:1535-1538.

13. Kessmann, H., Staub, T., Hofmann, C., Maetzke, T., Herzog, J., Ward, E., Uknes, S., and Ryals, J. 1994. Induction of systemic acquired resistance in plants by chemicals. Annu. Rev. Phytopathol. 32:439-459.

14. Lata, S., Sharma, B. K., and Raghava, G. P. S. 2007. Analysis and prediction of antibacterial peptides. BMC Bioinform. 8:263.

15. Lu, Y. Y., and Chen, C. Y. 1998. Probenazole-induced resistance of lily leaves against Botrytis elliptica. Plant Pathol. Bull. 7:134-140.

16. Lu, Y. Y., and Chen, C. Y. 2005. Molecular analysis of lily leaves in response to salicylic acid effective towards protection against Botrytis elliptica. Plant Sci. 169:1-9.

17. Lu, Y. Y., Liu, Y. H., and Chen, C. Y. 2007. Stomatal closure, callose deposition, and increase of LsGRPl-corresponding transcript in probenazole-induced resistance against Botrytis elliptica in lily. Plant Sci. 172:913-919.

18. Montesinos, E. 2007. Antimicrobial peptides and plant disease control. FEMS Microbiol. Lett. 270:1-11.

19. Pelegrini, B. P., del Sarto, R. P., Silva, O. N., Franco, O. L., and Grosside-Sa, M. F. 2011. Antibacterial peptides from plants: What they are and how they probably work. Biochem. Res. Int. 2011:250349. doi:10.1155/ 2011/250349

20. Rahnamaeian, M. 2011. Antimicrobial peptides: Modes of mechanism, modulation of defense responses. Plant Signal. Behav. 6:1325-1332.

21. Sharon, A., Finkelstein, A., Shlezinger, N., and Hatam, I. 2009. Fungal apoptosis: Function, genes and gene function. FEMS Microbiol. Rev. 33:833-854.

22. Shlezinger, N., Doron, A., and Sharon, A. 2011. Apoptosis-like programmed cell death in the grey mold fungus Botrytis cinerea: Genes and their role in pathogenicity. Biochem. Soc. Trans. 39:1493-1498.

23. Shlezinger, N., Minz, A., Gur, Y., Hatam, I., Dagdas, Y. F., Talbot, N. J., and Sharon, A. 2011. Anti-apoptotic machinery protects the necrotrophic fungus Botrytis cinerea from host-induced apoptotic-like cell death during plant infection. PLoS Pathog. 7:e1002185.

24. Sticher, L., Mauch-Mani, B., and Métraux, J. P. 1997. Systemic acquired resistance. Annu. Rev. Phytopathol. 35:235-270.

25. Stotz, H. U., Thomson, J. G., and Wang, Y. 2009. Plant defensins: Defense, development and application. Plant Signal. Behav. 4:10101012.

26. Thomas, S., Karnik, S., Barai, R. S., Jayaraman, V. K., and IdiculaThomas, S. 2010. CAMP: A useful resource for research on antimicrobial peptides. Nucleic Acids Res. 38:D774-D780.

27. Torrent, M., Nogués, V. M., and Boix, E. 2009. A theoretical approach to spot active regions in antimicrobial proteins. BMC Bioinform. 10:373.

28. Typas, A., Banzhaf, M., Gross, C. A., and Vollmer, W. 2011. From the regulation of peptidoglycan synthesis to bacterial growth and morphology. Nat. Rev. Microbiol. 10:123-136.

29. Van de Velde, W., Zehirov, G., Szatmari, A., Debreczeny, M., Ishihara, H., Kevei, Z., Farkas, A., Mikulass, K., Nagy, A., Tiricz, H., SatiatJeunemaître, B., Alunni, B., Bourge, M., Kucho, K., Abe, M., Kereszt, A., Maroti, G., Uchiumi, T., Kondorosi, E., and Mergaert, P. 2010. Plant peptides govern terminal differentiation of bacteria in symbiosis. Science 327:1122-1126.

30. Van Larebeke, N., Engler, G., Holsters, M., Van den Elsacker, S., Zaenen, I., Schilperoort, R. A., and Schell, J. 1974. Large plasmid in Agrobacterium tumefaciens essential for crown gall-inducing ability. Nature 252:169-170.

31. van Loon, L. C., Bakker, P. A. H. M., and Pieterse, C. M. J. 1998. Systemic resistance induced by rhizosphere bacteria. Annu. Rev. Phytopathol. 36:453-483.

32. Wang, G., Li, X., and Wang, Z. 2009. APD2: The updated antimicrobial peptide database and its application in peptide design. Nucleic Acids Res. 37:D933-D937.

33. Wang, Z., and Wang, G. 2004. APD: The antimicrobial peptide database. Nucleic Acids Res. 32:D590-D592. 